\title{
Disorganization of spleen compartments and dermatitis in canine visceral leishmaniasis
}

\author{
Claudia C. Santana', Luiz A. R. de Freitas ${ }^{2}$, Geraldo G. S. Oliveira ${ }^{3}$ and Washington L. C. dos-Santos ${ }^{3^{*}}$
}

\begin{abstract}
Canine visceral leishmaniasis is associated with splenic changes that may interfere with the surveillance of blood borne antigens. Dogs with terminal visceral leishmaniasis present with a variety of skin lesions that may reflect a failure of the immune system to cope with infection. In this study, we compare the frequency of dermatitis in dogs from an endemic area of visceral leishmaniasis and take account of the following parameters: presence/absence of laboratory markers of infection and susceptibility to visceral leishmaniasis, and presence/absence of splenic structural changes associated with severe forms of the disease. Dermatitis was present in 48 of 64 (75\%) of the animals. Dermatitis was more frequent in animals with positive splenic culture and negative leishmanin skin test $(14 / 15,93 \%)$ than in non-infected controls $(P=0.01)$. Diffuse dermatitis was present only in animals with evidence of Leishmania infection. Diffuse dermatitis was also more frequent in animals with positive $(9 / 27,33 \%)$ as opposed to negative $(3 / 34,9 \%)$ serology against Leishmania $(P=0.01)$. Presence of dermatitis correlated with both perisplenitis $(P=0.03)$ and with an increase in plasma cell density in the splenic tissue $(P=0.02)$. Diffuse dermatitis also correlated with splenic lymphoid tissue disorganization $(P=0.03)$ and germinal center atrophy $(P<0.01)$. The relationship between chronic dermatitis and spleen disorganization suggests an impairment of immune response to deal with skin aggressions in dogs with severe forms of visceral leishmaniasis. It also suggest that skin biopsy can be used in a model to define severity of canine visceral leishmaniasis.
\end{abstract}

Keywords: Leishmania chagasi, Canine visceral leishmaniasis, Spleen, Dermatitis, Dog, Leishmanin skin test

\section{Introuction}

Canine visceral leishmaniasis (CVL) is a re-emergent zoonotic disease caused by Leishmania infantum that is largely found in tropical and subtropical countries (Steverding 2017). This disease is characterized in both humans and dogs by emaciation, hepatosplenomegaly, fever, anemia, and a predisposition to bacterial infection (Costa et al. 2010)(Barrouin-Melo et al. 2006) (Lima et al. 2014). Furthermore, dogs present with a remarkable pattern of parasite dissemination to the skin with associated lesions that are uncommon in human beings (Lima et al. 2014). In fact, the high parasite burden in the skin of dogs with CVL support the idea that dogs play an

\footnotetext{
* Correspondence: wluis@bahia.fiocruz.br

${ }^{3}$ Fundação Oswaldo Cruz, Instituto Gonçalo Moniz, Centro de Pesquisas Gonçalo Moniz-FIOCRUZ, Rua Waldemar Falcão 121, Candeal, 40.296-710, Salvador, BA, Brazil

Full list of author information is available at the end of the article
}

important role as a reservoir in the L. infantum transmission cycle in urban centers. The most common dermatological manifestations in CVL include alopecia, desquamation, and nodular, ulcerative or papular dermatitis (Lima et al. 2014) (Perego et al. 2014). Hence, skin sampling from the ear and nose has been recommended for diagnosing CVL using conventional histology, immunohistochemistry, or PCR in symptomatic and asymptomatic dogs (Leontides et al. 2002) (Manna et al. 2004) (Xavier et al. 2006). A spectrum of inflammatory infiltrates varying from a focal (periadnexal) to a diffuse or granulomatous has been associated with CVL (Brachelente et al. 2005)(Dos-Santos et al. 2004)(Solano-Gallego et al. 2004). The predominant inflammatory cell types present in these inflammatory infiltrates are macrophages and plasma cells. Some patterns of inflammatory infiltrate have been associated with $L$. infantum infection and parasite burden (Dos-Santos et al. 2004). The factors

(c) The Author(s). 2019 Open Access This article is distributed under the terms of the Creative Commons Attribution 4.0 International License (http://creativecommons.org/licenses/by/4.0/), which permits unrestricted use, distribution, and 
that contribute to the presence and characteristics of the inflammatory infiltrate and the parasite burden in the skin are unknown. In tegumentar forms of leishmaniasis and other infectious diseases, such as leprosy, the pattern of inflammatory infiltrate reflects the immunological status of the host and the host's capability to control parasite proliferation (Lemos de Souza et al. 2000) (Lastoria and de Abreu 2014). A similar association between the characteristics of the inflammatory infiltrate and the host immunological response may also exist in CVL.

The spleen is affected in the whole course of visceral leishmaniasis (VL). It increases in size and develop white pulp hyperplasia followed by atrophy, red pulp plasmacytosis and structural disorganization (Veress et al. 1983) (Santana et al. 2008)(Silva-O'Hare et al. 2016). These changes interfere with important spleen functions. Spleen enlargement leads to hypersplenism, with enhanced erythrocyte destruction and blood cells and platelets retention leading to susceptibility to infection and bleeding (Costa et al. 2010)(dos-Santos et al. 2014). The structural disorganization of the spleen may impair spleen function of surveillance against pathogens circulating in the blood (Mebius and Kraal 2005) (Hermida et al. 2018). In CVL white pulp disruption is associated with severity of the disease (Lima et al. 2014). The spleen disorganization in CVL is associated with parasite burden and with changes in the normal leukocyte populations and in the normal pattern of cytokine expression (Lima et al. 2014) (Cavalcanti et al. 2015) (Silva et al. 2012).

In this work, we study the potential associations between dermatitis and disorganization of spleen compartments in dogs naturally infected with Leishmania. Our hypothesis is that the disruption of spleen structure may interfere with skin response to aggression by Leishmania and other pathogens. The skin is the first line of defense against infection. It is also the most accessible organ to clinical investigation for signs of disease. Hence, the study of skin lesions may help to design strategies of treatment of dogs with CVL and to predict spleen changes associated with severe forms of the disease.

\section{Materials and methods}

\section{Animal and specimens}

This is a retrospective study based on histological specimens and experimental records archived in the Gonçalo Moniz Institute-FIOCRUZ, Salvador, BA, Brazil. The histological specimens consisted of spleen and ear skin fragments obtained from stray dogs of different breeds and estimated ages that were collected in collaboration with the Endemic Diseases Surveillance Program of the State Health Service from the streets of Jequié (Bahia, Brazil, an endemic area for VL) from 1997 to 2001. The tissue samples had been fixed in $10 \%$ phosphate-buffered formalin and embedded in paraffin. In this study, we included all animals subjected to serology, splenic culture for Leishmania detection, and leishmanin skin test (LST) for which spleen and ear skin samples were available. Details about the tests performed in these animals were presented previously (Baleeiro et al. 2006)(dos-Santos et al. 2008), and the results of these tests are summarized in Table 1.

\section{Histological analysis}

Four to five-micron skin and splenic sections were stained with hematoxylin-eosin (H\&E) and Giemsa stain and were independently examined by at least two observers. Each animal was included in a single category of normal skin or dermatitis or of splenic alteration using the following criteria of histological analysis.

\section{Skin}

Skin inflammatory infiltrate was studied using previously defined categories (Dos-Santos et al. 2004) with the following modifications: (1) normal skin: without inflammatory infiltrate; (2) skin with mixed focal dermatitis: containing a variety of inflammatory cells including lymphocytes, macrophages, and plasma cells, present as single or multiple small clusters in the upper dermis and around the skin annexa; and (3) skin with mixed diffuse dermatitis: similar to the previous category but with extensive coalescent spreading of the inflammatory infiltrate through the dermis. Focal or diffuse dermatitis could be further classified as (a) with granuloma: focal or diffuse dermatitis containing clusters of epithelioid macrophages or (b) with monomorphic macrophage

Table 1 General characteristics of the stray dogs found in an endemic area of visceral leishmaniasis that were used in this study

\begin{tabular}{lll}
\hline Parameter & $N$ & $(\%)$ \\
\hline Total number of animals & 64 & $(100)$ \\
With emaciation & $26 / 60$ & $(43)$ \\
With positive spleen culture & $32 / 64$ & $(50)$ \\
With positive serology (ELISA) & $27 / 61$ & $(44)$ \\
With positive leishmanin skin test (L. chagasi antigen) & $29 / 47$ & $(51)$ \\
Spleen histology: & & \\
$\quad$ With normal white pulp (type I) & $32 / 64$ & $(50)$ \\
$\quad$ With white pulp disorganization: & $32 / 64$ & $(50)$ \\
$\quad$ Slight disorganization (type II) & $19 / 64$ & $(30)$ \\
$\quad$ Intense disorganization (type III) & $13 / 64$ & $(20)$ \\
Skin histology: & & \\
$\quad$ With normal histology & $16 / 64$ & $(25)$ \\
$\quad$ With dermatitis: & $48 / 64$ & $(75)$ \\
$\quad$ Focal dermatitis & $36 / 64$ & $(56)$ \\
$\quad$ Diffuse dermatitis & $12 / 64$ & $(19)$ \\
With Leishmania amastigotes & $8 / 64$ & $(13)$ \\
\hline
\end{tabular}


inflammatory infiltrate: focal or diffuse dermatitis containing large clusters of non-epithelioid, vacuolated macrophages (Vichowian-like inflammatory infiltrate). Representative aspects of each histological pattern were previously presented (Dos-Santos et al. 2004).

\section{Spleen}

A detailed description of splenic lesions is presented elsewhere and reviewed in Hermida et al. 2018 (Santana et al. 2008) (Hermida et al. 2018). Briefly, the presence of chronic perisplenitis and granuloma were recorded, and the following characteristics of the white pulp were semi-quantitatively estimated: lymphoid follicle and marginal zone frequency and size were classified as very small, small, average and large. The degree of structural organization of the white pulp was classified into four categories: Well organized spleen (spleen type 1) has a distinct periarteriolar lymphocyte sheath, lymphoid follicles and a marginal zone. Present a varied number of secondary lymphoid follicles, containing a germinal center clearly delimited by a rim of small lymphocytes (the mantle zone); slightly disorganized (spleen type 2) has either hyperplastic or hypoplastic changes blurring the boundaries between regions of the white pulp; and moderately to extensively disorganized (spleen type 3 ) the white pulp regions are poorly individualized or indistinct lymphoid follicles are barely distinct from the red pulp and T-cell areas and secondary lymphoid follicles are absent..

\section{Leukocyte populations in the skin and spleen}

The frequency of lymphocytes, plasma cells, macrophages, granulocytes, and mast cells present in the inflammatory foci of the skin and the spleen was estimated using conventional microscopy as either absent, rare (scattered cells present in discontinuous areas), few (small cell aggregates present in many areas of the inflammatory infiltrate), average (readily found in the inflammatory infiltrate), or high (representing one of the main cell populations in the inflammatory infiltrate). Details of the morphological identification of the cells are provided elsewhere (Silva et al. 2012).

\section{Histological parasitism in the skin and spleen}

The density of Leishmania amastigotes in the skin and spleen was estimated using conventional microscopy as described elsewhere (Santana et al. 2008). Briefly, the number of infected macrophages observed in a minimum of 40 and a maximum of 100 non-overlapping high power (1000x) fields per section was recorded. In the spleen, the examined fields were equally distributed between the subcapsular and internal red pulp.

\section{Statistical analysis}

The results are expressed in tables as absolute numbers and percentages. The significance of the differences observed between groups was tested using the Chi-square test with Yates' correction or Fisher's exact test when recommended. The strength of association between variables was tested using a standardized Pearson's contingency coefficient $\left(C^{*}\right)$. This coefficient ranges from -1 to +1 , indicating perfect association, where 0 (zero) indicates no association (Blaikie 2003) (Akoglu 2018). The following are proposed standards for association strength for Pearson's contingency coefficients: $0=$ poor, $0.01-0.20=$ slight, $0.21-0.39=$ fair, $0.40-$ $0.60=$ moderate, $0.61-0.80=$ substantial, and $0.81-1=\mathrm{al}-$ most perfect to perfect. The critical level of significance was established at $P<0.05$.

\section{Results}

Skin inflammation and Leishmania to infection

The data on the inflammatory infiltrate in the skin of the animals are summarized in Table 1 . Dermatitis was observed in 48 (75\%) out of 64 dogs. The inflammatory infiltrate was focal in 36 (56\%) animals (Fig. 1a) and diffuse in 12 (19\%) animals (Fig. 1b). The most frequent cells in the infiltrate were plasma cells and macrophages (Fig. 1c). Three of the 12 animals with diffuse dermatitis also had granulomas (Fig. 1d and e). Leishmania amastigotes were seen in the dermis of eight animals, five with diffuse dermatitis and three with focal dermatitis (Fig. 1f).

\section{Positive markers of infection, susceptibility to $\mathrm{VL}$, and presence of dermatitis}

Dermatitis was associated with evidence of Leishmania infection: among the 51 animals with positive splenic culture, positive serology, or positive LST, 41 (80\%) had dermatitis. Among the nine animals with all negative tests for Leishmania infection, only four (44\%) animals had dermatitis (Fisher exact test, $P<0.04$, Table 2). Dermatitis was focal in all animals without evidence of Leishmania infection.

Among the immunological and parasitological tests used in this study, positive anti-Leishmania serology and positive splenic culture but not LST were associated with presence of dermatitis (Table 2). Diffuse dermatitis was more frequent in animals with positive ( 9 out of 27 animals, 33\%) than negative serology (3 out of 34 animals, 9\%; Chi-square, $P=0.01$ ). Dermatitis was also more frequent in animals with positive (28 out of 32 animals, $88 \%$ ) than negative splenic culture (20 out of 32 animals, 63\%; Chi-square, $P=0.04$ ). Dermatitis was present in 24 (92\%) out of 26 emaciated animals and 23 (66\%) out of 35 animals that were not emaciated (Chi-square, $P=0.03$ ). Moreover, among the eight animals with histological parasitism of the skin, seven (87\%) were emaciated; among the 53 animals without histological parasitism of the skin, only 19 (36\%) were undernourished (Chi-square test, $P=0.02$ ). 


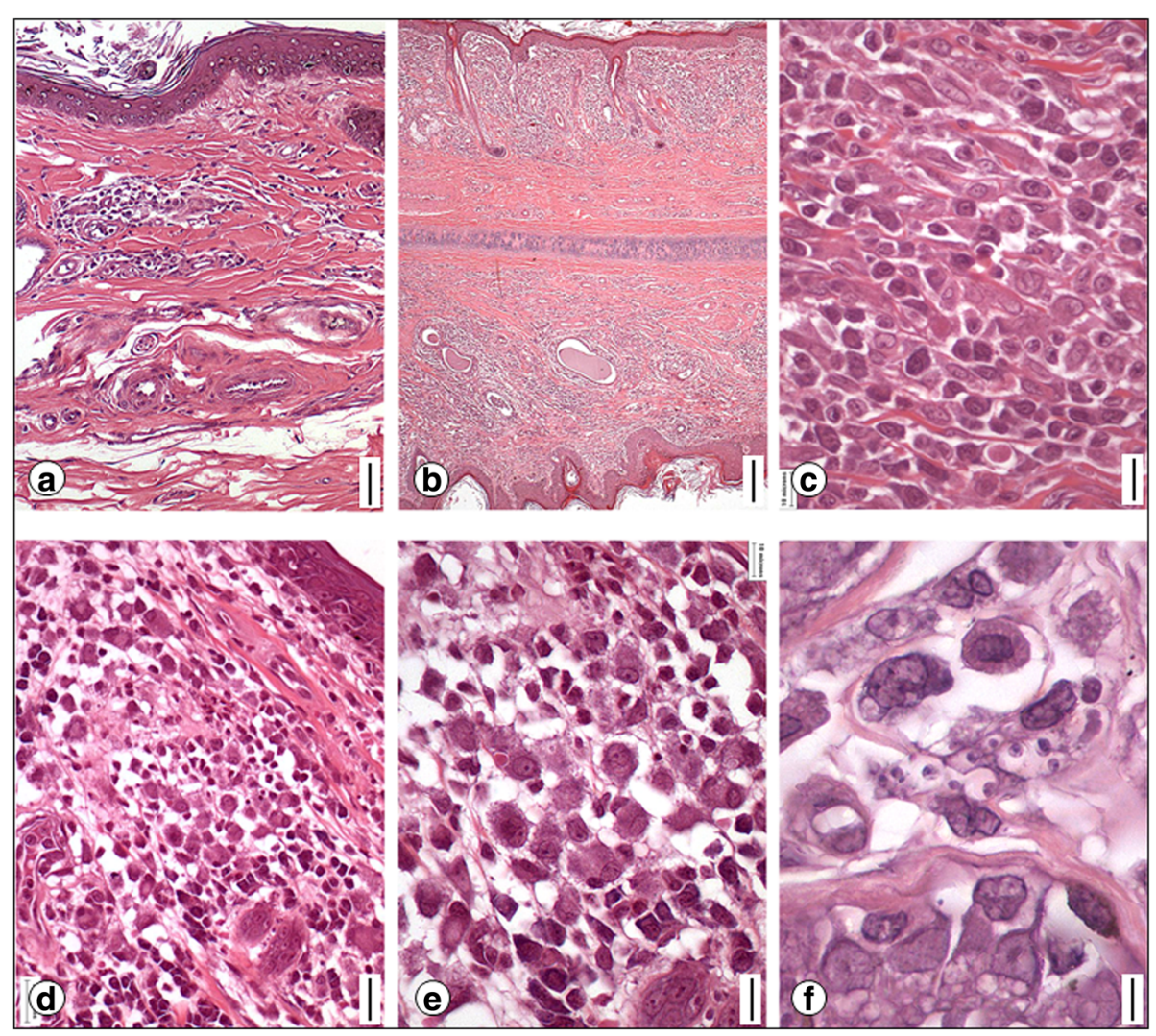

Fig. 1 Histological patterns of dermatitis present in dogs from an endemic area of visceral leishmaniasis: a focal dermatitis; $\mathbf{b}$ diffuse dermatitis; $\mathbf{c}$ inflammatory infiltrate with a predominance of plasma cell and macrophages; $\mathbf{d}$ inflammatory infiltrate with granulomatoid area; e a granuloma in detail; and $\mathbf{f}$ - amastigote-loaded macrophage in the dermis. Lengths of the black bars on the right hand side at the bottom of the figures: $\mathbf{a}$, $40 \mu \mathrm{m} ; \mathbf{b}, 100 \mu \mathrm{m} ; \mathbf{c}$ and $\mathbf{e}, 10 \mu \mathrm{m} ; \mathbf{d}, 20 \mu \mathrm{m} ; \mathbf{f}, 4 \mu \mathrm{m}$

Table 2 Frequency of dermatitis in stray dogs from an endemic area of visceral leishmaniasis according to laboratory tests for infection and clinical signs of disease

\begin{tabular}{|c|c|c|c|c|c|c|c|c|c|c|}
\hline \multirow[t]{3}{*}{ Parameter } & \multirow[t]{3}{*}{$N$} & \multirow[t]{3}{*}{ (\%) } & \multicolumn{8}{|l|}{ Skin } \\
\hline & & & \multirow[t]{2}{*}{ Normal } & \multirow[t]{2}{*}{ (\%) } & \multicolumn{6}{|c|}{ With dermatitis } \\
\hline & & & & & $\overline{\text { Focal }}$ & (\%) & Diffuse & (\%) & Total & (\%) \\
\hline \multicolumn{11}{|l|}{ Serology: } \\
\hline Negative & 34 & (100) & 12 & (35) & 19 & (56) & 3 & (9) & 22 & (65) \\
\hline Positive & 27 & (100) & 3 & (11) & 15 & (56) & 9 & $(33)^{\mathrm{a}}$ & 24 & $(89)^{b}$ \\
\hline \multicolumn{11}{|c|}{ Leishmanine skin test } \\
\hline Negative & 28 & (100) & 7 & (25) & 16 & (57) & 5 & (18) & 21 & (75) \\
\hline Positive & 29 & (100) & 8 & (28) & 17 & (59) & 4 & (14) & 21 & (72) \\
\hline \multicolumn{11}{|c|}{ Splenic culture } \\
\hline Negative & 32 & (100) & 12 & (38) & 17 & (53) & 3 & (9) & 20 & (63) \\
\hline Positive & 32 & (100) & 4 & (13) & 19 & (59) & 9 & $(28)^{c}$ & 28 & $(88)^{d}$ \\
\hline \multicolumn{11}{|l|}{ Emaciation: } \\
\hline Absent & 35 & (100) & 12 & (34) & 19 & (54) & 4 & (11) & 23 & (66) \\
\hline Present & 26 & (100) & 2 & (8) & 16 & (62) & 8 & $(31)^{e}$ & 24 & $(92)^{f}$ \\
\hline
\end{tabular}

${ }^{\mathrm{a}-\mathrm{f}}$ Statistically different from the group with normal skin, Chi-square test: ${ }^{\mathrm{a}} P=0.01 ;{ }^{\mathrm{b}} P=0.06,{ }^{\mathrm{c}} P=0.02 ;{ }^{\mathrm{d}} P=0.04 ;{ }^{\mathrm{e}} P=0.01 ;$ and ${ }^{\mathrm{f}} P=0.03$ 
Dermatitis was more frequent in the animals with positive culture or positive serology and negative LST (14 out of 15 animals, 93\%) than in non-infected animals (4 out of 9 animals, 44\%; Fisher exact test, $P=0.02$, Table 3).

\section{Associations between inflammatory changes in the skin and in the spleen in canine visceral leishmaniasis}

Dermatitis was moderately associated with splenic lymphoid tissue disorganization, increased splenic plasma cell frequency, and perisplenitis. Dermatitis was also strongly associated with splenic lymphoid follicle atrophy. Among 32 animals with disorganized splenic lymphoid tissue, 28 (88\%) had dermatitis, while 20 of 32 (63\%) animals with organized splenic lymphoid tissue had dermatitis (Chi-square, $P=0.02$; $C^{*}=0.39$;). Such associations were even stronger when only animals with diffuse dermatitis were considered (Chi-square, $P=0.03$; $C^{*}=0.54$, Table 4). Among the 36 animals with lymphoid follicles with small or no germinal centers, 32 (89\%) had dermatitis. Among the 28 animals with follicles containing average or large germinal centers, 16 (57\%) had dermatitis (Chi-square, $P<0.01 ; C^{*}=0.48$, Table 4). This association was stronger when only animals with diffuse dermatitis were considered (Chi-square, $P=0.01 ; C^{*}=$ 0.63 , Table 4). Among the 28 animals with a high frequency of splenic plasma cells, 25 (89\%) had dermatitis. Among the 36 animals with average or low concentrations of splenic plasma cells, 23 (64\%) had dermatitis (Chi-square, $P=0.02 ; C^{*}=0.39$, Table 4 ). Among the 19 animals with perispelenitis, 11 (58\%) had focal dermatitis, and seven (37\%) had diffuse dermatitis. Among the 42 animals without perisplenitis, 22 (52\%) had focal dermatitis, and $5(12 \%)$ had diffuse dermatitis (Chi-square, $P=0.03 ; C^{*}=0.40$, Table 4 ).

Table 3 Response to L. chagasi infection and frequency of dermatitis in stray dogs from an endemic area of visceral leishmaniasis

\begin{tabular}{llllllllll}
\hline Parameters & Uninfected & \multicolumn{1}{l}{ Infected } & & & \\
\hline Serology & - & & - & & + & & $-1+$ \\
Leishmanin skin test & - & & + & & - & & + & \\
Splenic culture & - & & - & & + & & + & \\
$N$ & 9 & $(100)^{\mathrm{a}}$ & 12 & $(100)$ & 15 & $(100)$ & 10 & $(100)$ \\
Skin histology: & & & & & & & & \\
$\quad$ Normal & 5 & $(56)$ & 3 & $(25)$ & 1 & $(7)$ & 2 & $(20)$ \\
$\quad$ With dermatitis: & 4 & $(44)^{\mathrm{b}}$ & 9 & $(75)$ & 14 & $(93)^{\mathrm{c}}$ & 8 & $(80)$ \\
$\quad$ Focal dermatitis & 4 & $(44)$ & 7 & $(58)$ & 10 & $(67)$ & 7 & $(70)$ \\
$\quad$ Diffuse dermatitis & 0 & $(0)$ & 2 & $(17)$ & 4 & $(27)$ & 1 & $(10)$ \\
\hline
\end{tabular}

${ }^{a}$ Values in parentheses are percentage from the total. ${ }^{\mathrm{b}}$ Statistically different from the other groups, Chi-square test, $P=0.0408$; $^{\mathrm{C}}$ Statistically different from the control uninfected group, Fisher's exact probability test, $P=0.02$
Leishmania amastigotes were seen both in the skin and spleen of five dogs in only the skin of three animals, and in only the spleen of four animals. Such concomitance of high parasite burden in the skin and spleen was statistically significant (Fisher exact test, $P<0.01$ ). All the animals with histological spleen parasitism also had dermatitis. The dermatitis was focal in five and diffuse in four animals. The difference in the frequency of dermatitis between animals with and without histological spelenic parasitism was not, however, statistically significant.

\section{Discussion}

Together with a previous study from our group, performed in another endemic area (Jacobina) $300 \mathrm{~km}$ north of Jequie, suggests that dermatitis is a frequent finding in stray dogs from endemic areas of VL in Brazil (Dos-Santos et al. 2004). In this series, $75 \%$ of the animals had inflammation in the skin. These data agree with Giunchetti and collaborators, who found dermatitis in $66 \%$ of dogs examined in the endemic area of Belo Horizonte $(770 \mathrm{~km}$ south of Jequie) (Giunchetti et al. 2006). In our study, even in the nine animals that had all three tests (splenic culture, LST and serology) negative for Leishmania infection, four of these animals had dermatitis. The causes of dermatitis in these animals are unknown. A variety of ordinary conditions, such as insect bites, trauma, and other parasitic infections, may be involved (Kim et al. 2011) (Mozos et al. 1999). In spite of this high dermatitis frequency, the dermatitis present in dogs without positive markers of infection with Leishmania was focal. On the other hand, the frequency of dermatitis was higher in animals with than without evidence of infection, and diffuse dermatitis was observed only in this group of Leishmania-infected dogs. In our previous study, a trend to association between dermatitis and infection was also observed (Dos-Santos et al. 2004).

In this work, we showed that dermatitis is associated with splenic lymphoid tissue disorganization, germinal center atrophy, and increased plasma cell frequency in the red pulp in CVL. These associations were of average to strong intensity (Pierson $\mathrm{C}$ coefficient). A variety of alterations of splenic histological architecture have been described in humans, mouse, and dogs throughout the course of VL (Veress et al. 1977) (Santana et al. 2008) (Cavalcanti et al. 2015) (Engwerda et al. 2002). Spleen enlargement leads to hypersplenism and pancytopenia, impairing host response to infection. Splenic white pulp disorganization in VL may disturb B-cell differentiation, affecting the immune response to blood-borne antigens (Mebius and Kraal 2005). In fact, an increased prevalence of bacterial infections is observed in the late stages of VL (Costa et al. 2010) (Endris et al. 2014). The clinical characteristics of some skin lesions in dogs with advanced VL are suggestive of bacterial infection, which 
Table 4 Associations between dermatitis and splenic changes in stray dogs from an endemic area of visceral leishmaniasis

\begin{tabular}{|c|c|c|c|c|c|c|c|c|c|c|c|}
\hline \multirow[t]{3}{*}{ Spleen } & \multirow[t]{3}{*}{ N } & \multirow[t]{3}{*}{ (\%) } & \multicolumn{8}{|c|}{ Skin } & \multirow{3}{*}{$\begin{array}{l}\text { Contingency } \\
\text { Coefficient }\end{array}$} \\
\hline & & & \multirow{2}{*}{\multicolumn{2}{|c|}{ Normal (\%) }} & \multicolumn{6}{|c|}{ With dermatitis } & \\
\hline & & & & & \multicolumn{2}{|c|}{ Focal (\%) } & \multicolumn{2}{|c|}{ Diffuse (\%) } & \multicolumn{2}{|c|}{ Total (\%) } & \\
\hline \multicolumn{12}{|c|}{ White pulp organization: } \\
\hline Organized & 32 & $(100)$ & 12 & (38) & 16 & (50) & 4 & (13) & 20 & (63) & \multirow{2}{*}{$\begin{array}{l}{ }^{\mathrm{a}} C^{*}=0.38, P=0.04 \\
{ }^{\mathrm{b}} C^{*}=0.54, P=0.03 \\
{ }^{\mathrm{c}} C^{*}=0.39, P=0.02\end{array}$} \\
\hline Disorganized & 32 & $(100)$ & 4 & (13) & 20 & $(63)^{a}$ & 8 & $(25)^{b}$ & 28 & $(88)^{c}$ & \\
\hline \multicolumn{12}{|c|}{ Lymphoid follicle germinal center: } \\
\hline \multirow[t]{2}{*}{ Average or large } & \multirow[t]{2}{*}{28} & \multirow[t]{2}{*}{$(100)$} & \multirow[t]{2}{*}{12} & \multirow[t]{2}{*}{ (43) } & \multirow[t]{2}{*}{13} & \multirow[t]{2}{*}{ (46) } & \multirow[t]{2}{*}{3} & \multirow[t]{2}{*}{ (11) } & \multirow[t]{2}{*}{16} & \multirow[t]{2}{*}{ (57) } & ${ }^{d} C^{*}=0.48, P=0.01$ \\
\hline & & & & & & & & & & & ${ }^{e} C^{*}=0.63, P=0.01$ \\
\hline Small or absent & 36 & $(100)$ & 4 & (11) & 23 & $(64)^{d}$ & 9 & $(25)^{e}$ & 32 & $(89)^{f}$ & ${ }^{f} C^{*}=0.48, P>0.01$ \\
\hline \multicolumn{12}{|l|}{ Marginal zone: } \\
\hline Average or large & 41 & (100) & 13 & (32) & 23 & (56) & 5 & (12) & 28 & (68) & NS \\
\hline Small or absent & 23 & (100) & 3 & (13) & 13 & (57) & 7 & (30) & 20 & (87) & \\
\hline \multicolumn{12}{|l|}{ Plasma cells: } \\
\hline Average to absent & 36 & (100) & 13 & (36) & 16 & (44) & 7 & (19) & 23 & (64) & ${ }^{g} C^{*}=0.46, P=0.01$ \\
\hline High & 28 & (100) & 3 & (11) & 20 & $(71)^{g}$ & 5 & (18) & 25 & $(89)^{\mathrm{h}}$ & ${ }^{h} C^{*}=0.39, P=0.02$ \\
\hline
\end{tabular}

$\mathrm{C}^{*}=$ Standardized Pearson's contingency coefficient, followed by the significance levels estimated using Chi-square test with Yates' correction. ${ }^{a}, b, c, d, e, f$ Represent the groups tested against the normal (without dermatitis) group and their respective association and significance tests

may reflect an impaired ability to fight these pathogens (Barrouin-Melo et al. 2006) (Lima et al. 2014). Dogs with severe VL also present an increased skin parasitism by Leishmania. Therefore, the disruption of spleen compartments observed in CVL may contribute to an impairment of skin immune response to different pathogens. Further studies are necessary in order to investigate the pathways involved in lymphoid tissue changes and dermatitis in CVL.

This work also shows that positive serology and active parasitism, both markers of susceptibility to VL, are associated with dermatitis. Conversely, LST alone did not show a clear association with dermatitis. It is interesting to note, however, that skin inflammation tended to be more frequent and severe in infected animals with negative LST (see Table 3). In tegumentary leishmaniasis, the inflammation pattern reflects the host immunological response to the parasite. In our previous study, we observed an association between granulomatous and monomorphic inflammatory infiltrate and high parasite burden in the skin (Dos-Santos et al. 2004). In this study, we only noticed a trend of increasing diffuse dermatitis frequency in the animals with positive culture or positive serology and negative LST. Unfortunately, we only had three animals with granulomatous infiltrate in this series, and animals with the monomorphic macrophage skin infiltrate was not observed in this sample, which impaired further stratification for analysis.

Finally, the data presented here suggest that the distribution pattern of dermatitis in CVL can be used in a model to predict susceptibility and progression of the disease.

\section{Conclusions}

1) Dermatitis is frequent in infected and uninfected dogs from endemic areas of VL in Brazil;

2) Dermatitis is, however, more frequent in dogs with than in dogs without infection with Leishmania, mostly in dogs with infection and a sign of susceptibility to VL;

3) In L. infantum-infected dogs, dermatitis is associated with spleen disorganization and susceptibility markers to VL.

\section{Abbreviations}

$C^{*}$ : Pearson's contingency coefficient; CVL: Canine visceral leishmaniasis; LST: leishmanin skin test; PCR: Polymerase chain reaction; VL: Visceral leishmaniasis

\section{Acknowledgements}

Authors would like to thank Ms. Claudia Zubieta, Ms. Danielle Tavares and Mr. Elmir Mateus Silva, for their assistance with the preparation of the histological samples used in the study.

\section{Funding}

This work was supported by the FAPESB (grant no. APR0434/2005) and Fundação OswaldoCruz (Fiocruz. http://portal.fiocruz.br/pt-br)-CNPq PROEP grant 400905/2013-2. WLCS received a scholarship from CNPq (http://www. cnpq.br/).

\section{Availability of data and materials}

The data and material used in the study can be made available by request to the corresponding author.

\section{Authors' contributions}

CCS - Designed and the study, wrote the paper. LARF - Designed the study and performed the histological analysis. GGSO - Designed the study and analyzed the data. WLCS - Designed the study, performed the histological 
analysis and wrote the paper. All authors read and approved the final manuscript.

\section{Ethics approval and consent to participate}

This study was performed using spleen and skin samples previously collected and stored in the histological records of the Gonçalo Moniz Institute in the period between 1997 to 2001. No new animal manipulations were performed. All the procedures involving animals were conducted in accordance with the Oswaldo Cruz Foundation guidelines for animal experimentation and with the manual for the surveillance and control of visceral leishmaniasis (http://bvsms.saude.gov.br/bvs/publicacoes/manual_ vigilancia_controle_leishmaniose_visceral.pdf) (Baleeiro et al. 2006).

\section{Consent for publication}

Not applicable.

\section{Competing interests}

The authors declare that they have no competing interests.

\section{Publisher's Note}

Springer Nature remains neutral with regard to jurisdictional claims in published maps and institutional affiliations.

\section{Author details}

${ }^{1}$ Escola Bahiana de Medicina e Saúde Pública, Salvador, Brazil. Universidade Federal da Bahia, Salvador, Brazil. ${ }^{3}$ Fundação Oswaldo Cruz, Instituto Gonçalo Moniz, Centro de Pesquisas Gonçalo Moniz-FIOCRUZ, Rua Waldemar Falcão 121, Candeal, 40.296-710, Salvador, BA, Brazil.

\section{Received: 12 April 2019 Accepted: 1 May 2019}

\section{Published online: 30 May 2019}

\section{References}

Akoglu H (2018) User's guide to correlation coefficients. Turkish J Emerg Med 18: 91-93. https://doi.org/10.1016/j.tjem.2018.08.001

Baleeiro CO, Paranhos-Silva M, dos Santos JC, Oliveira GGS, Nascimento EG, de Carvalho LP, dos-Santos WLC (2006) Montenegro's skin reactions and antibodies against different Leishmania species in dogs from a visceral leishmaniosis endemic area. Vet Parasitol 139:21-28. https://doi.org/10.1016/J. VETPAR.2006.02.033

Barrouin-Melo SM, Larangeira DF, de Andrade Filho FA, Trigo J, Julião FS, Franke CR, Palis Aguiar PH, Conrado dos-Santos WL, Pontes-de-Carvalho L (2006) Can spleen aspirations be safely used for the parasitological diagnosis of canine visceral leishmaniosis? A study on assymptomatic and polysymptomatic animals. Vet J 171:331-339. https://doi.org/10.1016/J.TVJL. 2004.11.010

Blaikie NWH (2003) Analyzing quantitative data : from description to explanation. Sage Publications

Brachelente C, Müller N, Doherr MG, Sattler U, Welle M (2005) Cutaneous Leishmaniasis in naturally infected dogs is associated with a T Helper-2biased immune response. Vet Pathol 42:166-175. https://doi.org/10.1354/vp. 42-2-166

Cavalcanti AS, Ribeiro-Alves M, Pereira L d OR, Mestre GL, Ferreira ABR, Morgado FN, Boité MC, Cupolillo E, Moraes MO, Porrozzi R (2015) Parasite load induces progressive spleen architecture breakage and impairs cytokine mRNA expression in Leishmania infantum-naturally infected dogs. PLoS One 10: e0123009. https://doi.org/10.1371/journal.pone.0123009

Costa CHN, Werneck GL, Costa DL, Holanda TA, Aguiar GB, Carvalho AS, Cavalcanti JC, Santos LS (2010) Article / Artigo is severe visceral leishmaniasis a systemic inflammatory response syndrome ? - a case control study a leishmaniose visceral grave é uma síndrome da resposta inflamatória sistêmica ? - um estudo. Rev Soc Bras Med Trop 43:386-392

dos-Santos WL, Pagliari C, Santos LG, Almeida VA, e Silva TL, Coutinho J d J, Souza T, Duarte Ml, de Freitas LA, Costa CH (2014) A case of conventional treatment failure in visceral leishmaniasis: leukocyte distribution and cytokine expression in splenic compartments. BMC Infect Dis 14:491. https://doi.org/ 10.1186/1471-2334-14-491

Dos-Santos WLC, David J, Badaro R, De-Freitas LAR (2004) Association between skin parasitism and a granulomatous inflammatory pattern in canine visceral leishmaniosis. Parasitol Res 92:89-94. https://doi.org/10.1007/s00436-0031016-1
dos-Santos WLC, Jesus EE, Paranhos-Silva M, Pereira AM, Santos JC, Baleeiro CO, Nascimento EG, Moreira ED, Oliveira GGS, Pontes-de-Carvalho LC (2008) Associations among immunological, parasitological and clinical parameters in canine visceral leishmaniasis: emaciation, spleen parasitism, specific antibodies and leishmanin skin test reaction. Vet Immunol Immunopathol 123:251-259. https://doi.org/10.1016/JVETIMM.2008.02.004

Endris M, Takele Y, Woldeyohannes D, Tiruneh M, Mohammed R, Moges F, Lynen L, Jacobs J, van Griensven J, Diro E (2014) Bacterial sepsis in patients with visceral leishmaniasis in Northwest Ethiopia. Biomed Res Int 2014:361058. https://doi.org/10.1155/2014/361058

Engwerda CR, Ato M, Cotterell SEJ, Mynott TL, Tschannerl A, Gorak-Stolinska PMA, Kaye PM (2002) A role for tumor necrosis factor-a in remodeling the splenic marginal zone during Leishmania donovani infection. Am J Pathol 161:429437. https://doi.org/10.1016/50002-9440(10)64199-5

Giunchetti RC, Mayrink W, Genaro O, Carneiro CM, Corrêa-Oliveira R, Martins-Filho OA, Marques MJ, Tafuri WL, Reis AB (2006) Relationship between canine visceral leishmaniosis and the Leishmania (Leishmania) chagasi burden in dermal inflammatory foci. J Comp Pathol 135:100-107. https://doi.org/10. 1016/J.JCPA.2006.06.005

Hermida M d'E-R, de Melo CVB, Lima IDS, Oliveira GG d S, Dos-Santos WLC (2018) Histological disorganization of spleen compartments and severe visceral Leishmaniasis. Front Cell Infect Microbiol 8:394. https://doi.org/10.3389/fcimb. 2018.00394

Kim HJ, Kang MH, Park HM (2011) Common allergens of atopic dermatitis in dogs: comparative findings based on intradermal tests. J Vet Sci 12:287-290. https://doi.org/10.4142/jvs.2011.12.3.287

Lastoria JC, de Abreu MAMM (2014) Leprosy: a review of laboratory and therapeutic aspects - part 2. An Bras Dermatol 89:389-401. https://doi.org/10. 1590/abd1806-4841.20142460

Lemos de Souza V, Ascenção Souza J, Correia Silva TM, Sampaio Tavares Veras P, Rodrigues de-Freitas LA (2000) Different Leishmania species determine distinct profiles of immune and histopathological responses in CBA mice. Microbes Infect 2:1807-1815. https://doi.org/10.1016/S1286-4579(00)01340-X

Leontides LS, Saridomichelakis MN, Billinis C, Kontos V, Koutinas AF, Galatos AD, Mylonakis ME (2002) A cross-sectional study of Leishmania spp. infection in clinically healthy dogs with polymerase chain reaction and serology in Greece. Vet Parasitol 109:19-27. https://doi.org/10.1016/ S0304-4017(02)00201-7

Lima IS, Silva JS, Almeida VA, Junior FGL, Souza PA, Larangeira DF, Moura-Neto JP, Fraga DB, de Freitas LAR, dos-Santos WLC (2014) Severe clinical presentation of visceral Leishmaniasis in naturally infected dogs with disruption of the splenic white pulp. PLoS One 9:e87742. https://doi.org/10. 1371/journal.pone.0087742

Manna L, Vitale F, Reale S, Caracappa S, Pavone LM, Morte RD, Cringoli G, Staiano N, Gravino AE (2004) Comparison of different tissue sampling for PCR-based diagnosis and follow-up of canine visceral leishmaniosis. Vet Parasitol 125: 251-262. https://doi.org/10.1016/JVETPAR.2004.07.019

Mebius RE, Kraal G (2005) Structure and function of the spleen. Nat Rev Immunol 5:606-616. https://doi.org/10.1038/nri1669

Mozos E, Pérez J, Day JD, Lucena R, Ginel PJ (1999) Leishmaniosis and generalized demodicosis in three dogs: a clinicopathological and immunohistochemical study. J Comp Pathol 120:257-268. https://doi.org/10. 1053/jcpa.1998.0273

Perego R, Proverbio D, Bagnagatti De Giorgi G, Spada E (2014) Prevalence of dermatological presentations of canine leishmaniasis in a nonendemic area: a retrospective study of 100 dogs. Vet Med Int 2014:374613. https://doi.org/ $10.1155 / 2014 / 374613$

Santana CC, Vassallo J, de Freitas LAR, Oliveira GGS, Pontes-de-Carvalho LC, dosSantos WLC (2008) Inflammation and structural changes of splenic lymphoid tissue in visceral leishmaniasis: a study on naturally infected dogs. Parasite Immunol 30:515-524. https://doi.org/10.1111/j.1365-3024.2008.01051.x

Silva JS, Andrade AC, Santana CC, Santos LQ, de Oliveira CI, Veras PST, Vassallo J, dos-Santos WLC (2012) Low CXCL13 expression, splenic lymphoid tissue atrophy and germinal center disruption in severe canine visceral Leishmaniasis. PLoS One 7:e29103. https://doi.org/10.1371/journal.pone. 0029103

Silva-O'Hare J, de Oliveira IS, Klevorn T, Almeida VA, Oliveira GGS, Atta AM, de Freitas LAR, dos-Santos WLC (2016) Disruption of splenic lymphoid tissue and Plasmacytosis in canine visceral Leishmaniasis: changes in homing and survival of plasma cells. PLoS One 11:e0156733. https://doi.org/10.1371/ journal.pone.0156733 
Solano-Gallego L, Fernández-Bellon H, Morell P, Fondevila D, Alberola J, Ramis A, Ferrer L (2004) Histological and Immunohistochemical study of clinically Normal skin of Leishmania infantum-infected dogs. J Comp Pathol 130:7-12. https://doi.org/10.1016/50021-9975(03)00063-X

Steverding D (2017) The history of leishmaniasis. Parasit Vectors 10:82. https://doi. org/10.1186/s13071-017-2028-5

Veress B, Abdalla RE, El Hassan AM (1983) Visceral spreading depletion of thymus-dependent regions and amyloidosis in mice and hamsters infected intradermally with Leishmania isolated from Sudanese cutaneous leishmaniasis. Br J Exp Pathol 64:505-514

Veress B, Omer A, Satir AA (1977) Morphology of the spleen and lymph nodes Xavier SC, Andrade HM, Hadad SJ, Chiarelli IM, Lima WG, Michalick MSM, Tafuri WL, Tafuri WL (2006) Comparison of paraffin-embedded skin biopsies from different anatomical regions as sampling methods for detection of Leishmania infection in dogs using histological, immunohistochemical and PCR methods. BMC Vet Res 2:17. https://doi.org/10.1186/1746-6148-2-17

Ready to submit your research? Choose BMC and benefit from:

- fast, convenient online submission

- thorough peer review by experienced researchers in your field

- rapid publication on acceptance

- support for research data, including large and complex data types

- gold Open Access which fosters wider collaboration and increased citations

- maximum visibility for your research: over $100 \mathrm{M}$ website views per year

At $\mathrm{BMC}$, research is always in progress.

Learn more biomedcentral.com/submissions 